\title{
Peran Budaya Sekolah Dalam Pembentukan Sikap Disiplin Siswa Kelas X MAN 3 Kota Palembang

\author{
Andarusni Alfansyur ${ }^{1}$, Akmal Hawi ${ }^{2}$, Saipul Annur ${ }^{2}$, Win Afgani ${ }^{2}$, Maryamah Maryamah $^{2}$ \\ ${ }^{1}$ MAN 3 Kota Palembang \\ ${ }^{2}$ UIN Raden Fatah Palembang \\ Email: aandarusni@gmail.com
}

\begin{abstract}
Abstrak
Artikel ini bertujuan untuk mengetahui peran budaya sekolah dalam pembentukan sikap disiplin siswa kelas X MAN 3 Kota Palembang. Latar belakang dalam penelitian ini adalah bahwa penting untuk mengembangkan sikap disiplin seorang siswa di tengah perubahan zaman. Metode yang dipakai dalam artikel ini adalah studi kasus dengan teknik wawancara dan studi dikumentasi. Hasil yang didapatkan adalah sistem sekolah boarding school memiliki program, sumber daya dan waktu yang lebih banyak dalam melakukan pembiasaan agar terbentuk personal karakter dan publik karakter siswa karena pembentukan sikap disiplin yang konsisten.

Kata kunci: Budaya Sekolah, MAN 3 Kota Palembang, Sikap Disiplin

\section{Abstract}

This article aims to determine the role of school culture in the formation of discipline attitudes of class X MAN 3 Palembang City students. The background in this research is that it is important to develop a disciplined attitude of a student in the midst of changing times. The method used in this article is a case study with interview techniques and documented studies. The results obtained are that the boarding school system has more programs, resources and time in making habituation in order to form the personal character and public character of students because of the formation of a consistent discipline attitude.
\end{abstract}

Keyword: Discipline, MAN 3 Palembang, School Culture

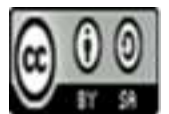

\begin{tabular}{l|l} 
Received: May 6, 2021 & Revised: December 26, 2021
\end{tabular}

Accepted: December 27, 2021 


\section{Pendahuluan}

Kualitas pendidikan di Indonesia senantiasa ditingkatkan oleh pemerintah, salah satunya melalui pembelajaran yang menekankan pada pembentukan karakter. Pembentukan karakter yang dimaksud ialah membentuk manusia yang baik (being good) dan manusia yang cerdas (being smart). Pemerintah melalui Kementerian Pendidikan dan Kebudayaan pada tahun 2016 membentuk Gerakan Penguatan Pendidikan Karakter (PPK) yang merupakan program kelanjutan dan kesinambungan dari Gerakan Nasional Pendidikan Karakter Bangsa Tahun 2010. Program ini juga merupakan bagian integral 8 Nawacita yang meliputi Revolusi Karakter Bangsa dan Gerakan Revolusi Mental dalam pendidikan yang bermaksdu hendak mendorong seluruh pemangku kepentingan untuk mengadakan perubahan paradigma, yaitu pola pikir dan cara bertindak, dalam mengelola sekolah yang berubah (Perpres No 87 Tahun 2017).

Program PPK memiliki lima nilai karakter utama dengan subnilai masing-masing yang saling berkaitan membentuk jejaring nilai yang perlu dikembangkan sebagai prioritas Gerakan PPK meliputi nilai gotong royong, nasionalis, nilai religius, nilai mandiri, dan nilai integritas. Nilai-nilai utama yang terdiri dari lima nilai karakter tersebut bukanlah nilai yang terpisah akan tetapi nilai tersebut berinteraksi dan berkembang satu sama lain secara dinamis dan membentuk secara utuh kepribadian seseorang. Kelima nilai utama karakter dalam program PKK tersebut memiliki subnilai masing-masing yang berinteraksi dan memberikan kontribusi yang berbeda-beda yang dijadikan prioritas. Salah satu subnilai yang dikembangkan melalui program PPK ialah disiplin yang merupakan subnilai dari nilai mandiri (Kemendikbud, 2016).

Pentingnya nilai disiplin menjadi salah satu nilai yang dikembangkan juga dikarenakan melalui nilai disiplin tersebut akan mampu membentuk nilai-nilai lainnya. Hal ini diperkuat oleh pernyataan Lickona (Lickona, 2012) bahwa pembentukan nilai disiplin yang baik akan membentuk nilai-nilai baik lainnya. Pembentukan siswa yang disiplin merupakan salah satu rumusan dari tujuan sekolah, mengingat bahwa tujuan sekolah merupakan turunan dari tujuan nasional yang mengharapkan pembentukan siswa berkarakter secara utuh. Pembentukan karakter dalam hal ini sikap disiplin menjadi tanggung jawab setiap mata pelajaran yang ada di sekolah.

Permasalahan yang terjadi saat ini dalam dunia pendidikan, salah satunya masih terdapat kasus siswa yang melanggar tata tertib sekolah, menggunakan narkoba dan obat terlarang, tawuran, dan adanya pertemanan kelompok teman sebaya yang sering menunjukkan tindakan kekerasan. Komisi Nasional Perlindungan Anak dan Badan Narkotika Nasional (BNN) menunjukkan hasil survei bahwa di Indonesia remaja usia SMP dan SMA sebanyak 63\% sudah melakukan hubungan seks di luar nikah dan pengguna narkotika di Indonesia sebanyak $22 \%$ dari kalangan pelajar dan mahasiswa. Memperkuat hasil survei di atas maka di awal 2017, LSM Plan Internationall and International Center for Research on Womenn (ICRW) menunjukkan fakta bahwa masih tingginya kasus kekerasan anak di sekolah yang mencapai persentase $84 \%$ anak di Indonesia mengalami kekerasan. Angka tersebut menunjukkan bahwa kasus kekerasan tersebut lebih tinggi dari rata-rata yang terjadi di kawasan Asia yakni 70\% (Liputan 6.com, diakses 12 Januari 2021). Pendapat Ginanjar (Ginanjar, 2008) juga menguatkan hasil survei bahwa ada tujuh krisis moral di masyarakat Indonesia, yaitu 1) rendahnya kejujuran; 2) rendahnya tanggung jawab; 3) tidak berpikir jauh ke depan; 4) rendahnya disiplin; 5) rendahnya kebersamaan; 6) keadilan yang belum terwujud; dan 7) krisis kepedulian.

Fenomena diatas memperlihatkan mulai terjadi degradasi moral di kalangan remaja, yang mengindikasikan bahwa pentingnya sikap disiplin untuk diintegrasikan dalam pembelajaran di sekolah karena salah satu indikator keberhasilan pendidikan adalah tumbuhnya sikap disiplin pada siswa. Aqib (Aqib \& Sujak, 2011) mengemukakan bahwa disiplin ialah perilaku yang mencerminkan perilaku tertib dan patuh terhadap berbagai ketentuan dan peraturan yang berlaku. Perilaku patuh dan tertib dapat bersifat melekat dan menjadi kebiasaan sehingga membentuk kesadaran secara sendirinya dalam melakukan sesuatu. Hal ini juga sejalan bahwa disiplin merupakan indikator penting dalam proses belajar mengajar di sekolah. Disiplin dimaksudkan 
bahwa semua tindakan yang menunjukkan perilaku tertib aturan dan patuh pada ketentuan dan peraturan (Albertus, 2012).

Salah satu keunikan dari MAN 3 Palembang adalah budaya sekolah yang terintegrasi dengan asrama boarding school dimana tujuan dari boarding school tersebut yang dituangkan dalam buku tata tertib siswa juga menjelaskan bahwa sistem asrama bertujuan untuk melatih kedisiplinan, kemandirian, sosialitas, budaya serta peningkatan kemampuan praktek keagamaan dan kebahasaan. Berdasarkan hasil studi pendahuluan yang dilakukan masih terjadi beberapa pelanggaran disiplin yang dilakukan oleh siswa kelas X MAN 3 Palembang, yang dituliskan sebagai catatan khusus pada buku laporan siswa dengan sistem pemberian skor sesuai dengan tingkat aturan yang dilanggar yang berimplikasi pada sanksi yang harus mereka dapatkan.

Upaya penanaman budaya sekolah dalam menumbuhkan karakter siswa, baik karakter sosial maupun religiusnya, telah dilakukan oleh beberapa peneliti diantaranya Abidah Utiya (2019) dalam penelitiannya menemukan bahwa penanaman budaya sekolah melalui pembiasaan kegiatan pengembangan diri secara rutin dapat membentuk karakter siswa. Selain itu pembudayaan karakter juga dapat dilakukan melalui gerakan literasi sekolah, ekstra kurikuler, pembiasaan di awal dan akhir proses belajar, dan pembiasaan perilaku baik yang bersifat spontan, serta menetapkan tata tertib sekolah (Soedarsono, 2003). Beberapa penelitian ini belum upaya yang dapat dilakukan sekolah sebagai bentuk budaya sekolah yang mampu membentuk karakter siswa khususnya karakter disiplin pada sekolah boarding school, oleh karena itu pada artikel ini penulis akan menyajikan peran budaya sekolah terutama dengan tipe boarding school dalam menumbuhkan karakter disiplin siswa.

\section{Metode Penelitian}

Metode yang digunakan dalam penulisan artikel ini adalah dengan metode studi kasus yang dilaksanakan di MAN 3 Kota Palembang. Menurut Moleong (Moleong, 2015) studi kasus bertujuan untuk menggali suatu permasalahan secara mendalam. Dalam artikel ini teknik pengumpulan data melalui wawancara sebagai teknik primernya, sedangkan melalui teknik dokumentasi merupakan teknik sekundernya demi mendapatkan informasi yang yang saling melengkapi selama wawancara, lalu hasil dari pengumpulan data dianalisis dengan teknik analisis data deskriptif.

\section{Hasil dan Pembahasan}

Pendidikan karakter menjadi salah satu sarana untuk menginternalisasikan nilai-nilai yang ada dan berkembang dalam kehidupan nyata. Nilai-nilai yang dikembangkan diharapkan membentuk kebiasaan dalam wujud sikap yang konsisten. Salah satu nilai karakter yang diharapkan ialah sikap disiplin. Sikap disiplin merupakan hal penting dan utama dalam membentuk karakter seseorang. Berbekal nilai karakter sikap disiplin maka akan mendorong terbentuknya nilai karakter yang baik lainnyaseperti tanggung jawab, kerjasama, kejujuran, peduli sosial, dan sebagainya.

Sikap disiplin adalah salah satu faktor yang paling efektif dalam proses belajar. Tujuan utama dari sikap disiplin adalah untuk menciptakan lingkungan pendidikan dan kesempatan untuk proses pembelajaran. Sikap disiplin dalam proses pembelajaran sebagai alat untuk mewujudkan tujuan pendidikan yang mengarah pada pertumbuhan siswa dan kemajuan dalam setiap dimensi (Ghorbani, 2013). Hal ini juga sejalan pendapat Prijodaminto ialah kondisi yang tercipta dan terbentuk melalui serangkaian perilaku yang berproses yang pada akhirnya menunjukkan beberapa nilai seperti ketaatan, lalu kepatuhan, kesetiaan, keteraturan serta ketertiban. Nilai yang akan terbentuk akan bersifat melekat menjadi bagian dalam kehidupan seseorang melalui pembinaan keluarga, pendidikan dan pengalaman (Prijodarminto, 2009).

Pengembangan sikap patuh dan taat pada aturan dan ketentuan yang ada akan mampu mengendalikan diri dan sikap mentalnya sendiri berdasarkan dorongan dan kesadaran yang 
muncul pada diri orang tersebut. Perilaku patuh dan tertib dapat bersifat melekat dan menjadi kebiasaan sehingga membentuk kesadaran secara sendirinya dalam melakukan sesuatu (Albertus, 2012).

Pendapat di atas lebih menekankan pada nilai agar seseorang patuh maka berbeda pendapat di atas Husdarta mengemukakan bahwa sikap disiplin ialah kontrol penguasaan terhadap impuls yag tidak diinginkan atau proses mengarahkan impuls pada suatu tujuan atau cita-cita untuk mencapai dampak yang lebih besar dan bermanfaat (Husdarta, 2009).

Berdasarkan pendapat di atas maka pada hakikatnya sikap disiplin merupakan kondisi yang ditunjukkan melalui sikap taat dan patuh seseorang terhadap ketentuan dan peraturan yang ada. Sikap tersebut pada akhirnya muncul secara alamiah dari diri sendiri. Ketaatan tersebut dilakuan dalam usaha untuk memperoleh perubahan baik berupa pengetahuan, keterampilan dan sikap sebagai hasil dari latihan-latihan yang dilakukan untuk menumbuhkan karakter sikap disiplin ini membutuhkan dukungan dari semua warga sekolah dan orang tua.

Menentukan seseorang tersebut sikap disiplin atau belum haruslah memiliki kriteria tertentu yang memudahkan seseorang dalam mengkategorikan dalam penelitian ini. Sikap disiplin yang dimaksud dalam hal ini ialah perilaku siswa yang menunjukkan pada ketaatan terhadap sebuah aturan dan apabila dilanggar akan dikenakan sanksi. Berdasarkan indikator yang telah terstandar dengan baik Kemendiknas mengemukakan indikator sikap disiplin meliputi: a) pembiasaan hadir tepat waktu, b) pembiasaan patuh pada aturan yang ada, c) pembiasaan berpakaian sesuai aturan yang berlaku (Kemendikbud, 2010). Secara lebih rinci indikator sikap disiplin menurut Gunarsa meliputi jujur, tepat waktu, tegas dan tanggung jawab (Gunarsa, 2014).

Sikap disiplin merupakan salah satu subnilai utama yang dikembangkan dalam pendidikan karakter di Indonesia. Sikap disipin juga menjadi salah satu nilai utama yang dikembangkan dalam mata pelajaran PKN. Hal ini diperkuat oleh pendapat dari Cholisin (Cholisin, 2011) bahwa terdapat nilai karakter utama yang dikembangkan dalam mata pelajaran PKn. Karakter utama yang dikembangkan meliputi kepatuhan pada aturan sosial, nasionalisme, menghargai keberagaman, bertanggung jawab, kesadaran akan hak dan kewajiban diri dan orang lain, berpikir logis, kreatif, kritis, inovatif dan kemandirian. Sikap disiplin juga menjadi salah satu nilai yang dikembangkan untuk membentuk warga negara yang baik. Hal ini sesuai dengan hasil penelitian (CCE, 1998) mengemukakan bahwa dalam pembentukan karakter atau nilai kebajikan warga negara maka harus mengembangakan dua karakter warga negara yang meliputi: 1) personal character (moral responsibility, self discipline, respect for individual dignity, and diversity of opinion (empathy); 2) public character respect for the law, willingness to participate in public affairs, commitment to the rule of the majority with respect for the rights of the minority, commitment to the balance between selfinterestaand the commonn welfare, willingness to seek changes in unjust laws in pecafeul and legal manner.

Pembentukan sikap disiplin penting dibentuk karenakan nilai disiplin menjadi nilai utama yang mampu membentuk nilai-nilai lainnya. Selain itu bahwa indikator utama dalam memberikan gambaran pendidikan suatu negara berhasil atau belum salah satunya dapat dilihat dengan indikator nilai disiplin dan tanggung jawab warganya (Muslich, 2011). Pembentukan disiplin dipengaruhi oleh dua faktor utama yaitu faktor internal (kesadaran, motivasi dan kemauan) dan faktor eksternal (keluarga, sekolah dan masyarakat). Faktor-faktor tersebut memberikan sumbangsih dan saling bekerjasama dalam membentuk sikap disiplin siswa. Faktor-faktor yang difokuskan dalam penelitian ini ialah faktor eksternal sekolah yang terdiri atas budaya sekolah, iklim kelas dan program boarding. Hal diasumsikan oleh peneliti merupakan faktor yang berpengaruh besar dalam pembentukan sikap disiplin siswa.

Budaya sekolah merupakan salah satu faktor eksternal pembentuk perilaku disiplin siswa di sekolah. Budaya sekolah pada hakikatnya membentuk karakter salah satunya ialah disiplin. Upaya membentuk budaya sekolah sangat diperlukan konsensus bersama semua warga sekolah yang ada menjadi norma perilaku pada setiap orang yang berupa nilai, adat istiadat dan kebiasaan baik bersifat positif maupun negatif. Nilai-nilai budaya sekolah yang biasanya dikembangkan ialah 
kepemimpinan, keteladanan, keramahan, toleransi, disiplin, kerja keras, kepedulian lingkungan, rasa kebangsaan.

Besarnya pengaruh budaya sekolah terhadap pembentukan perilaku disiplin menunjukkan bahwa budaya sekolah menjadi komponen penting dalam mencapai tujuan pendidikan karakter. $\mathrm{Hal}$ itu diperkuat hasil penelitian Andari (Andari, 2003) dan Hongboontri (Hongboontri \& Keawkhong, 2014) bahwa budaya sekolah memberikan pengaruh terhadap pembentukan karakter di sekolah. Salah satu karakter yang berhasil terbentuk ialah perilaku disiplin siswa. Beberapa upaya yang dapat dilakukan dalam membentuk perilaku disiplin siswa di sekolah salah satunya melalui kegiatan dalam pengembangan budaya sekolah seperti pembiasaan keteladanan, pembiasaan spontan, pembiasaan rutin dan pengkondisian. Upaya meningkatkan budaya sekolah yang positif maka akan memberikan banyak dampak positif ialah meningkatkan hasil akademik, sosial dan perilaku positif bagi semua siswa. Budaya sekolah yang tidak dibentuk dengan baik tidak akan mendukung pembentukan sikap disiplin siswa.

Pembentukan sikap disiplin akan lebih efektif jika dibentuk melalui sistem pendidikan boarding school. Sistem boarding school merupakan konsep pengintegrasian tiga fungsi pendidikan baik keluarga, sekolah dan masyarakat menjadi alternatif untuk mampu mengatasi kesenjangan antara ketiga fungsi tri pusat pendidikan. Hal ini juga dikemukakan Shane (Shane, 2008) bahwa melalui pendidikan dengan sistem boarding ini ialah integrasi keluarga, sekolah dan lingkungan sekitar mampu membentuk dan mengembangkan nilai-nilai dengan motivasi yang tinggi, memiliki sikap disiplin, dan tanggung jawab. Sistem pendidikan ini terbentuk karena sekolah berbasis boarding mengharapkan siswa mampu menjadi bagian dari masyarakat baik di kelas maupun di luar kelas dengan pembiasaan yang dilakukan melalui indoktrinasi nilai dan promosi kebudayaan. Fathurrahman (Fathurrahman, 2012) juga mengemukakan bahwa beberapa aspek pendukung terwujudnya pendidikan karakter di sekolah ialah a) modeling; b) sistem pendidikan yang bebas dan menyenangkan; c) sistem boarding school; d) model pembelajaran kooperatif; e) guru yang cerdas, humanis dan religius serta f) komunikasi. Salah satu kelebihan sistem boarding school dibanding sekolah umum ialah program yang ditawarkan kepada siswa lebih tersusun dan terarah dibanding dengan sekolah umum. Program boarding school inilah yang akan membantu siswa untuk membentuk sikap disiplin siswa di sekolah maupun asrama.

\section{Kesimpulan}

Sikap disiplin sangat penting untuk dikembangkan dan miliki oleh setiap individu, karena nilai disiplin menjadi salah satu nilai yang dikembangkan juga dikarenakan melalui nilai disiplin tersebut akan mampu membentuk nilai-nilai lainnya. Bagi siswa kelas X MAN 3 Kota Palembang dimana sistem budaya sekolah yang terintegrasi dengan boarding school maka sangat berperan dalam membentuk sikap disiplin, besarnya peran budaya sekolah terhadap pembentukan perilaku disiplin menunjukkan bahwa budaya sekolah menjadi komponen penting dalam mencapai tujuan pendidikan karakter, budaya sekolah memberikan pengaruh terhadap pembentukan karakter di sekolah.

\section{Daftar Pustaka}

Albertus, A. (2012). Pendidikan karakter utuh dan menyeluruh. Yogyakarta: Kanisius.

Andari, L. (2003). Pengaruh Budaya Sekolah terhadap Karakter Siswa (Studi di SDN Jumeneng Lor Mlati Sleman). Yogyakarta: UNY.

Aqib, A., \& Sujak, S. (2011). Panduan dan aplikasi pendidikan karakter untuk SD/MI, SMP/MTS, $S M A / M A$, SMK/SMK. Bandung: Yrama Widia.

CCE. (1998). We the People Project Citizen, Teacher Guide. Calabacas: Center of Civic Education.

Cholisin, C. (2011). Peran guru PKn dalam pendidikan karakter. Makalah Kuliah Umum Jurusan PPKn FKIP UAD Palembang. Yogyakarta: UAD. 
Fathurrahman, P. (2012). Model of the character education in developing countries. Journal of Applied Sciences Research, 8(3), 1813-1816.

Ghorbani, S. (2013). nvestigating the effect of positive discipline on the learning process and its achieving strategies with focusing on the students' abilities. International of Academic Research in Business and Social Science, 1(1), 305-314.

Ginanjar, A. (2008). Pembentukan habit menerapkan nilai-nilai religius, sosial dan akademik. Yogyakarta: UNY.

Gunarsa, S. (2014). Psikologi untuk membimbing. Jakarta: Gunung Mulia.

Hongboontri, C., \& Keawkhong, N. (2014). School Culture: teachers' Beliefs, Behaviors, and Instructional Practices. Australian Journal of Teacher Education, 39(5), 1-12.

Husdarta, H. (2009). Manajemen Pendidikan Jasmani. Bandung: Alfabeta.

Kemendikbud. (2010). Pengembangan Pendidikan Budaya dan Karakter Bangsa. Jakarta: PuskurBalitbang Kemdiknas.

Kemendikbud. (2016). Pedoman Penguatan Karakter. Jakarta: Kemendikbud.

Lickona, T. (2012). Character matters (persoalan karakter). Jakarta: Bumi Aksara.

Moleong, L. J. (2015). Metode Penelitian Kualitatif. Bandung: PT. Remaja Rosdakarya.

Muslich, M. (2011). Pendidikan karakter: menjawab tantangan krisis multidimensional. Jakarta: Bumi Aksara.

Prijodarminto, S. (2009). Disiplin kiat menuju sukses. Jakarta: PT. Abadi.

Shane, E. (2008). Military boarding school perspectives of parental choice: a qualitative inquiry. Journal of School Choice :International Research and Reform, 2(2), 178-198.

Soedarsono, S. (2003). Character Building: Membentuk Watak. Jakarta: Elex Media Komputindo. 